\title{
BIOFUELS AND FOOD: CAN BRAZILIAN ETHANOL PRODUCTION AFFECT DOMESTIC FOOD PRICES?
}

\author{
Daniel Henrique Dario Capitani *
}

\begin{abstract}
Resumo
O crescimento na produção de biocombustíveis tem promovido um debate sobre seus efeitos na segurança alimentar, objetivando o presente trabalho a avaliar os possíveis impactos da produção brasileira de etanol sobre os preços domésticos de alimentos. Para isso, utiliza-se um modelo autorregressivo estrutural com correção de erros (VECM), incluindo, também, o preço internacional do petróleo e a taxa de câmbio. Os resultados apontam para uma baixa influência do etanol sobre os demais preços, inferior ao do petróleo e taxa de câmbio. Os choques simulados nos preços do etanol não apontam influências significativas sobre outros preços. Neste sentido, os possíveis efeitos adversos da produção de biocombustível não se aplicam ao Brasil.
\end{abstract}

Palavras-chave: Biocombustíveis; Etanol; Cana-de-açúcar; Análise de Preços; Modelos autorregressivos.

\begin{abstract}
The increasing production of biofuels has promoted a debate on the effect of biofuels on food prices. This paper examines the impact of Brazilian domestic ethanol production on several local agricultural food commodities, using a structural autoregressive model with error correction (VECM). Other variables are included in the model, such as oil prices and exchange rate. Overall, results indicate that Brazilian ethanol has a low impact on domestic food commodity prices, even less than impacts of oil and exchange rate. Simulated price shocks for ethanol do not seem to have significant influence overestimated commodity prices. Results suggest that concerns expressed in the biofuel-food debate have little relevance in the Brazilian ethanol context.
\end{abstract}

Keywords: Biofuel; Ethanol; Sugarcane; Price Analysis; Autoregressive Model.

JEL classification: C32, Q02, Q11, Q16.

DOI: http://dx.doi.org/10.11606/1980-5330/ea124294

\footnotetext{
* Assistant Professor, School of Applied Sciencies, University of Campinas (FCA/UNICAMP). Email: daniel.capitani@fca.unicamp.br.
} 


\section{Introduction}

The prices of agricultural commodities have exhibited significant increases since the early 2000s. For many commodities, international prices reached near or at record levels over the period. Simultaneously, biofuel production has expanded around the world. The two most important producers, USA and Brazil, had a remarkable increase in their ethanol production during the 20002015. USA corn ethanol production grew from 15 billion liters to 65 billion liters, while Brazilian sugarcane production increased from 10 to 29 billion liters (RFA, 2015; UNICA, 2015). In addition, Brazilian biodiesel production expanded from 0.7 billion liters to 4 billion liters from 2005 to 2015 (ABIOVE 2016).

The rise in biofuel production resulted from policies in the industrialized countries since 1990-2000s which actively supported domestic biofuel industries in order to achieve energy security and to develop a direct substitute for fossil fuels. The major purpose of these policies was to reduce the use of fossil fuels and, consequently, greenhouse gas emissions. However, many tradeoffs from biofuel increases were pointed out in order to understand the benefits of the change from fossil fuel to biofuels use. As result of these concerns, sustainability became an essential condition for the long-term feasibility of biofuels and for public support for biofuels (Elbehri et al. 2013).

One of these questions has stimulated the food vs. fuel debate and raised questions about the potential contribution of biofuels to the increasing of food prices (Hochman et al. 2011, Chen \& Khanna 2013). The biofuel-food correlation prompted several studies to assess the possible increases in biofuel production, prices, and their effect on the price of food commodities (Vacha et al. 2013). In high-income countries, however, with crops comprising a small share of the final cost of food in the consumer basket, the impact of biofuels on food prices tends to be smaller in terms of consumer budget constraints than in low-income countries, where expenditure on less processed food is higher, while income levels are lower (Hochman et al. 2011)

The most important research questions relating to the development of biofuels are based on economic modeling of direct and indirect land use change (LUC, iLUC) or focused on commodity price relationships concerned with understanding the impact of increased biofuel production and consumption (Serra \& Zilberman 2013, Kristoufek et al. 2014). Thus, the relationships between food, energy, biofuels, and commodity prices have become a pertinent topic for discussion and accurate analysis regarding the sustainability of biofuel production emerging from several studies in different markets (Timilsina et al. 2011, Vacha et al. 2013, Kristoufek et al. 2014).

Overall, most of the economic studies have focused their analysis on the USA corn ethanol market using a partial equilibrium model to assess LUC and iLUC impacts, or estimating econometric models to evaluate relationships between prices of ethanol, feedstocks and fossil fuels. However, few studies have assessed biofuel and food price associations in the emerging markets, where food security issues are more relevant. In Brazil, despite traditional ethanol production and the recent expansion of sugarcane cropland, a small number of studies have been conducted which mostly assess the impacts of LUC and iLUC (Nassar et al. 2011, Chen \& Khanna 2013, Nuñez et al. 2013).

Other studies have had the central proposition of assessing price linkages in the Brazilian ethanol market using alternative statistical or econometric 
models and have limited their analysis to ethanol, gasoline, oil, and sugar (Rapsomanikis \& Hallam 2006, Balcombe \& Rapsomanikis 2008, Drabik et al. 2015, Kristoufek et al. 2015). Thus, there is a gap in research, namely studies proposing the inclusion of other important variables in an econometric time series model to explain the dynamics of ethanol and food prices at a domestic level. This is relevant, considering the number of food commodities which are produced near sugarcane croplands in Brazil. Furthermore, many of these food commodities are largely exported. Therefore, the model demands the inclusion of new variables to capture the particular dynamics of this market.

Regarding concerns about potential effects of biofuel production on food and energy, especially in the developing countries, the objective of this paper is to assess the impact of sugarcane ethanol prices on the price of major crops and food commodities in the Brazilian market. The empirical discussion will rely on the study of sugarcane expansion since the establishment of a bi-flex fuel vehicle fleet in 2003, which encouraged the increase in sugarcane cropping, mostly destined for hydrous ethanol production. Brazil is the largest sugarcane producer in the world, and the biggest sugar and ethanol exporter. In the past few decades, domestic production was concentrated in the Southeast, substantially in Sao Paulo State East and central areas. Recently, production has expanded to other areas in Sao Paulo and other nearby states, especially the Midwest, to traditional extensive agricultural land with crops and cattle production. Thus, investigation of the hypothetical effects of sugarcane ethanol production on regional food prices and production is required.

Results of this study can provide a more comprehensive analysis of the relationship between commodity prices and biofuels in one of the most important bioethanol markets in the world. The findings of this investigation can contribute to those of other recent studies concerning the biofuel and food debate, and give a better understanding of the impact of biofuels on Brazilian domestic food commodity prices. The inclusion of food prices for commodities largely produced in Brazil, as well as the exchange rate and oil prices in a structural auto-regressive model with error correction can help to explain the dynamics of agricultural commodities prices in Brazil, as well as contributing to an understanding of the particular consequences for this market of rapid ethanol expansion.

\section{Background}

The food crisis of 2008 generated a large number of studies examining the causes of peaks in food commodity prices. The growing importance of the biofuels vs. fuel debate has encouraged research interested in the most relevant markets. Initially, several studies proposed an impacts assessment of US corn ethanol production on crop production and food commodity prices (Rajagopal et al. 2007, Sexton et al. 2008, Ajanovic 2011, Zhang et al. 2010, Hochman et al. 2012, Serra et al. 2011b). One of the first studies that proposed an investigation of the increase of US corn ethanol (Rajagopal et al. 2007) employed a conceptual microeconomic model with a back-of-the- envelope estimate of wealth transfers resulting from US ethanol production. The study concluded that the partial government subsidies for corn used for ethanol production were balanced by a positive net energy balance in comparison to gasoline production. However, the authors warned of the socioeconomic impact 
of biofuel production that is largely dependent on the adoption of technology and management of different biomass and crop supply chains.

Sexton et al. (2008) estimated the impact of USA ethanol production on food and fuel markets and their effects on welfare. The authors developed a global multi-market partial equilibrium model which considered two regions (USA and the rest of world) and comprised of corn, soybean, biofuel and gasoline markets. The different scenarios using 2007 data led to the conclusion that US ethanol production had significantly reduced gasoline prices, but had simultaneously contributed to international food shortages, warning of the need to adopt new technologies and increase the yield of crops used for biofuel production.

Hochman et al. (2012) developed a partial equilibrium model to quantify the influences of biofuel production on increasing food prices during the period of 2001-2008, including the food commodities inventory. The study showed that, if inventory effects were not taken into account, the impact of biofuel production and several other factors on food commodity prices inflation would be overestimated. The estimated empirical model pointed out that if the inventory is properly accounted for, the external impact on food prices exhibits a significant reduction. The study also revealed that other factors, such as speculation, trade policy and weather shocks, might be partly responsible for food price inflation and should be taken into account.

To understand the relationship between corn, ethanol, gasoline, and oil prices in the USA market, Serra et al. (2011b) estimated an autoregressive vector model and the long-run price relationships. The study found that both corn and gasoline prices partly explain domestic ethanol prices, suggesting that corn biorefineries may suffer losses if the price of ethanol does not fully adjust to the eventual rise in corn prices. Zhang et al. (2009) developed a similar study, applying multivariate autoregression estimators to assess the volatility of wholesale prices of ethanol, corn, soybeans, gasoline, and oil in the USA market using data from 1989 through 2007. In general, the results indicate that gasoline prices influence oil and ethanol prices, while ethanol prices may only have short-term effects on agricultural prices, not long-term.

However, as shown, discussion in the published literature is generally unclear concerning the effects of ethanol on other commodity markets, which is probably a consequence of using several methodological approaches with different assumptions and modeling calibrations, resulting in different conclusions (Hochman et al. 2011, Zilberman et al. 2012, Vacha et al. 2013). Thereby, the interest in the biofuel production tradeoffs can be associated with the possible impact on food commodity prices and, consequently, over food security in developing countries. Therefore, the importance of emerging markets in ethanol production, such as Brazil, associated with the low number of studies focused on these markets has prompted research to further the understanding of how biofuel production can affect domestic crops-food production and prices in the second largest ethanol producer in the world.

The economic impact of sugarcane expansion in Brazil has been discussed in a few studies using different methodological approaches. For example, Nassar et al. (2011) discussed the main methodologies used to quantify aspects of changed land use resulting from the expansion of biofuel production. This study highlighted the problem of models that focus on GHG emissions related to the agricultural sector, rather than emphasizing on biofuel production. Following these results, it is apparent that many studies have discussed and/or 
applied partial equilibrium models to assess aspects of land use change in crop production, pastures and forest. Chen \& Khanna (2013) investigated the major effect of biofuel policies on USA food prices using a multi-market and multi-period equilibrium model. Nuñez et al. (2013) investigated biofuel policies in Brazil and USA and developed a mathematical model to estimate the impact of biofuel mandates and trade distortions on land use, agricultural commodity and transportation fuel markets, as well as on the global environment. Martinez et al. (2013) proposed an investigation of the socioeconomic impact of bioethanol production in the Brazilian Northeast using an input-output model concerned with estimating the added-value, imports and employment derived from increased regional biofuel production. Other studies have proposed a detailed examination of the long-term relationship between domestic food prices and ethanol production in Brazil, especially ethanol, gasoline, sugar, and oil prices (Rapsomanikis \& Hallam 2006, Balcombe \& Rapsomanikis 2008, Serra 2011, Serra et al. 2011a, Kristoufek et al. 2015).

As with previous studies of other markets, price analysis research studies have dealt with price transmission and causality effects on the food-biofuels system. Attempts to theoretically model the food-biofuels price relationship are relatively new and have generally focused on evaluating patterns in price levels. Time series models may be useful for predicting the signs, price behavior and relative magnitude of the impact, rather than partial equilibrium models, that differ in terms of complexity and underlying assumptions. In addition, some general statistical properties of time-series dynamics should be considered to provide accurate price forecasts (Serra \& Zilberman 2013). A central property of time-series is that the dynamics of a system of variables may be characterized by the existence of a long-term relationship and a builtin tendency to adjust to this equilibrium (Chen et al. 2010, Serra \& Zilberman 2013).

The price level interaction between biofuels and commodity markets has mainly focused on the US biofuel market, using different data and periodicity. Most of these studies have examined the association between biofuels and feedstock prices also using fossil fuel prices. The most common methodological approaches used in studies focused on the US market are cointegration analysis, Granger causality test, as well as the estimation of a Vector AutoRegressive Model with errors correction (VECM) (Serra \& Zilberman 2013).

Rapsomanikis \& Hallam (2006) conducted the first study involving price analysis of the Brazilian biofuel market using non-linear versions of error- correction models to understand sugar-oil and ethanol-oil relationships, finding that crude oil drives long-term prices of ethanol and sugarcane in Brazil. A similar study by Balcombe \& Rapsomanikis (2008) investigated the long-run relationship between ethanol, sugar and oil prices. Their findings pointed out to the influence of oil prices on ethanol and sugar prices, as well as the effect of sugar prices on domestic ethanol prices. The conclusions of the study suggest that biofuels do not appear to have any significant impact on commodity prices in this market.

Serra et al. (2011a) assessed volatility spillovers in Brazilian ethanol, oil and sugar markets. Their findings suggest that volatility transmission directions are from oil and sugar markets for the ethanol market. Another study aimed at understanding oil-sugar-ethanol price transmissions in Brazil was developed by Serra (2011), using nonparametric correction to time series esti- 
mations they also found that oil and sugar prices drove ethanol prices in one direction.

Kristoufek et al. (2015) used a wavelet coherence methodology to investigate the relationship between ethanol and feedstock prices in the USA and Brazil. This method enables the discovery of price connections and their evolution simultaneously, as well as the frequency domain in both markets. The study showed that, even in USA and in Brazil, there was a long-run relationship between ethanol prices and it feedstock or substitute (corn and sugar prices), being strong and stable in time. As in the other studies, the authors identified that feedstocks drove ethanol prices both in the short- and longterm.

Despite the heterogeneity of the modeling reported in the literature, even among studies that estimated distinct econometric models, it is noted that previous studies using econometric background essentially included few variables directly related to ethanol production as the main feedstocks (e.g. corn and sugarcane) and close substitute goods (gasoline, oil and sugar). Furthermore, the analysis of food and biofuel competition in emerging countries, such as Brazil, are less frequent, more homogenous and indicate the absence of important variables that may contribute to a better understanding of the dynamics of domestic food commodity markets.

Taking this into consideration, this research proposes to bring new elements to the discussion, focusing on Brazil, an emerging country and second largest ethanol producer in the world. Thus, this study aims to support and shed new light on elements of the biofuel vs food debate, especially in the emerging markets, since the measurement of possible impacts of ethanol production on several food markets, including the most relevant grain and protein domestic markets, as well as those crop/livestock areas that are closest to the expanding sugarcane area. In addition, the study investigated other important variables that may affect food prices in Brazil, such as oil prices and exchange rates, estimating all variables together in a structural autoregressive model with error correction.

\section{Methods}

This study uses a times-series framework for the analysis of fuel and agricultural prices, proposing a methodological approach that comprises cointegration analysis and the estimation of a Structural VECM, consisting of a system of simultaneous equations that enable the dependency relationships between the variables to be obtained. Furthermore, this method can provide a variance decomposition of forecast errors, as well as estimate structural shocks through an impulse-response function from a structured contemporaneous relationship matrix, as proposed by Sims (1986) and Bernanke (1986).

The impulse-response function provides the forecast of impulse elasticities for $k$ futures periods. The elasticities represent the behavior of price variables following shocks in one variable based on their past and current errors, enabling forecast of the path of simultaneous shocks under the system variables. The variance decomposition of predictable errors helps the understanding of the portion of each variable in the explanation of the others, showing the evolution of their dynamic behavior and enabling the determination of the predictable errors that can be explained by the variable itself, as 
well by the others (Enders 2004). Further, the Structural VECM improves the autoregressive vector with errors correction estimation for the contemporaneous relationship of the variables system, allowing an indication of the proper number of matrix restrictions, regarding the economic theory, and the restriction of maximum number of contemporaneous restrictions (Hamilton 1944). The structural VECM consists of a structural VAR with errors correction. The SVAR is represented by the following equation:

$$
B_{0 x t}=B_{1 x t-1}+B_{2 x t-2}+\ldots+B_{p x t-p}+e_{t}
$$

where $\boldsymbol{x}_{t}$ is the vector of each system variable; $\boldsymbol{B}_{j}$ are the matrices $(n \times n)$ for each $j ; \boldsymbol{B}_{0}$ is the matrix of contemporaneous relationships; and $\boldsymbol{e}_{t}$ is a vector $n \times 1$ of orthogonal shocks where the components are not serially correlated.

The errors corrections are considered in the SVAR if the cointegration analysis points to the existence of a long-run relationship in the simultaneous variables system. The cointegration analysis adopted is based on the methodological approach proposed by (Johansen 1988). The Johansen test is indicated on models with two or more variables. This test provides the ranking of a number of cointegration vectors and can be expressed by the following equation:

$$
\Delta y_{t}=\sum_{i=1}^{p-1} \Gamma_{i} \Delta y_{t-i}+\Pi y_{t-1}+\mu+\psi d_{t}+\epsilon_{t}
$$

where $y_{t}$ is a vector $(k \times 1)$ of variables $I(1) ; \epsilon_{t}\left(0, \sum\right)$ and $E\left(\epsilon_{t} \epsilon_{s^{\prime}}\right)=0$ for each $t$ different than $s$; and $\boldsymbol{d}$ is vector of binary variables to capture the stationary variation.

The Johansen test, as well as the VECM, are applied to combinations of ethanol prices and agricultural commodity prices as the feedstock that represents some of the most important agricultural markets in Brazil. Also, other important variables that can affect domestic commodity prices are included, such as international oil prices and the exchange rate.

The cointegration test must be preceded by a test of nonstationarity for each individual variable under consideration. For this study, the augmented Dickey-Fuller (ADF) unit root test was considered. The test is generated from the following regression:

$$
\Delta y_{t}=\alpha+\beta_{t}+\eta y_{t-1}+\sum_{i=1}^{p-1} \phi_{i} \Delta y_{t-1}+e_{t}
$$

where $y_{t}$ is the variable assessed; $\alpha$ is a constant; $\beta$ is the coefficient on a time trend; $p$ is the lag order of the autoregressive process; and $\boldsymbol{e}_{t}$ is the stochastic term of white noise. In addition, the GLS transformed Dickey-Fuller test (DFGLS) is employed. The procedure for the DF-GLS unit root test is efficient in terms of power, using the transformed data to perform a usual ADF unit root test (Ng \& Perron 2001).

\section{Empirical Model}

One of the advantages of the autoregressive vector model is the low degree of requirement of theoretical restrictions under its structure, i.e., it is required only the specificity of the variables groups that interact into the system and 
the determination of the lag criteria to obtain the variables interaction dynamics. In addition, the Bernanke and Sims decomposition 6 of the Structural autoregressive vector enables to estimate only the proper variables interactions into the system, according to the model restrictions.

Therefore, the empirical model used in the SVAR with error correction model admits that food commodity prices (dependent variables) may be affected by ethanol prices (independent variable). Consequently, the contemporaneous relationship adopts these propositions. However, considering the importance of international, prices on the cost of production of commodities, the proposed model also takes into account the possible effect of this fossil fuel over food commodity prices. Additionally, the large volume of Brazilian commodity exports within a scenario of high volatility in the exchange rate, the model also considers the Brazilian Real/US Dollar exchange, especially to explain the commodity group traded on the international market. Therefore, the model premises are that ethanol may affect all food commodity prices, oil prices may influence the cost of production of some commodities, and the exchange rate can have significant effects on some large-volume traded commodities. Thus, the summarized structured multi-regression system estimated using SVAR modeling is expressed as:

$$
\begin{gathered}
P_{i}^{f \text { ood }}=\beta_{1}+\beta_{2} P_{i}^{\text {ethanol }}+\beta_{3} P_{i}^{\text {oil }}+D_{1}+D_{2}+\epsilon_{i} \\
P_{i}^{\text {trade food }}=\beta_{1}+\beta_{2} P_{i}^{\text {ethanol }}+\beta_{3} P_{i}^{\text {oil }}+\beta_{3} P_{i}^{\text {exchange rate }}+D_{1}+D_{2}+\epsilon_{i}
\end{gathered}
$$

$P_{i}^{f \text { ood }}$ represents whole food commodities in the estimated system; $P_{i}^{\text {trade food }}$ represents the food commodities that may be mostly affected by the exchange rate; $D_{1}$ and $D_{2}$ are two dummy variables for better adjustment of the model, with $D_{1}$ representing the positive peak of international food prices, and $D_{2}$ the period of Brazilian federal intervention policies concerning domestic gasoline prices. Note that this multi-equation system requires other equations changing the ordination of dependent and explanatory variables, as well as the introduction of their lag criteria.

Thus, in addition to the general regressions expressed above, the SVAR estimates other particular regressions, including some variables that may have strong relationships, such as sugar and oil prices over ethanol prices, and soybean over corn prices.

\section{Data}

Data for the empirical analysis consist of monthly domestic cash prices of: ethanol and sugar prices in Sao Paulo State; the most important agricultural commodity markets near the Sao Paulo sugarcane area; oil; and the Brazilian exchange rate. All agricultural commodity prices were obtained from the Center for Advanced Studies and Applied Economics of the University of Sao Paulo (CEPEA) for the period from February 2004 through February 2016 (145 observations). In addition to ethanol prices (hydrous), the model included sugar, soybeans, corn, wheat, rice, cassava (starch), and cattle (livestock). In addition, the model comprised the international oil prices (Europe Brent spot price) and the real exchange rate between Brazilian Real and the 
US dollar. Two dummy variables are used. The first, relating to the periods of peaks in international commodity prices during 2008-2009, was to control the impact of exogenous issues on commodity price behavior. The second dummy variable relates to the period 2011-2016 which included the intervention by the Brazilian government in gasoline prices and suppressing the regular (free) volatility in the domestic ethanol prices, especially the positive price deviations ${ }^{1}$.

\section{Results}

Before exploring the main findings from the time series models estimation, a chart analysis is presented to illustrate the behavior of commodity and fuel prices $^{2}$ during the period of 2004-2016 (Figures 1 and 2). Overall, agricultural commodity prices in Brazil had similar trade behavior during the periods considered in this study (Figure 1). Most prices exhibited an abnormal increase through 2007-2009, which results from the general increase in international commodity prices. Sugar and cassava prices exhibited higher volatility over the period, but not necessarily behaving in the same way as other prices. The ethanol prices showed a peak during the first quarter of 2011, but generally has less volatility than other prices (Figure 2). An important observation is the increase in ethanol prices during 2015-2016, after years of strong federal intervention in gasoline prices.

For the price series stationarity analysis, the augmented Dickey-Fuller unit root test was employed to assess the null hypothesis of the unit root in each variable. The price series were transformed to a logarithm basis and tested for the existence of a unit root. The test statistics supported the presence of a unit root in the level data indicating non-stationarity in each of the price series ${ }^{3}$. After testing the same procedure with the inclusion of one difference in the price series, the results suggest the lack of a unit root with $99 \%$ confidence level for each series. The Dickey-Fuller test results are shown in Table 1 and 2, for ADF and DF-GLS unit root test.

The Johansen trace test applied to combination of fuel prices, agricultural prices and exchange rate detected the presence of a long-run relationship between them ${ }^{4}$. The results pointed to the presence of three cointegration vectors at the 5\% significance level (Table 3). To investigate the long-run relationship between the variables, as well as their particular short-run interactions, the VECM was estimated.

\footnotetext{
${ }^{1}$ Another series of agricultural prices were initially considered, such as anhydrous ethanol, sugarcane and nearby markets of orange juice, dairy (milk), broiler and pork. However, some of the price series were at a stationary level (e.g. anhydrous ethanol, sugarcane, orange juice and dairy products) and their use was not applicable. Moreover, in order to attend statistical properties of the autoregressive model, the decision points out not to use sugarcane, broiler and pork prices, once the identification of cointegration and unidirectional causality of cattle prices in both broiler and pork prices, and from hydrous ethanol and sugar prices on sugarcane prices.

${ }^{2}$ Grain and cereals prices (R \$/tons) deflated by general price index (IGP-DI). Note that time series estimations uses logarithmical from these prices, although Figures 1 and 2 indicate real prices at original scale.

${ }^{3}$ The exceptions were corn (ADF and DF-GLS tests) and rice prices (ADF test) only with interception, at $5 \%$ significant level. The others ADF and DF-GLS tests in level for both corn and rice suggest nonstationarity for these prices.

${ }^{4} \mathrm{Lag}$ length determination test suggests the use of one lag in the estimation of the Johansen test, as well as in the VECM.
} 


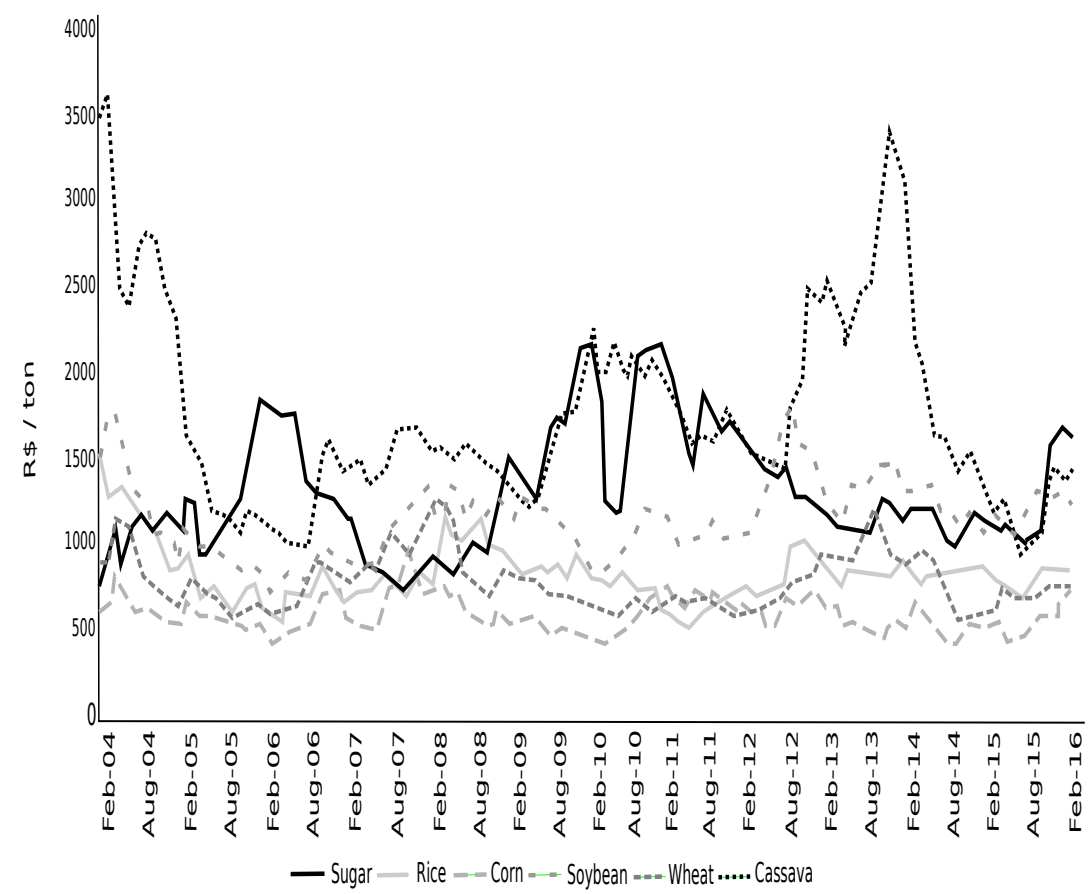

Source: CEPEA (2016)

Figure 1: Monthly cash prices for agricultural crops in Brazil, 2004-2016

Table 1: Results from ADF unit root test for each variable

\begin{tabular}{lccccccccc}
\hline & \multicolumn{1}{c}{$\tau_{\tau}$} & Prob & \multicolumn{1}{c}{$\tau_{\mu}$} & Prob $\tau$ & Prob & $\Delta \tau$ & Prob & Lags \\
\hline Cassava & $-2,789$ & 0,204 & $-2,771$ & 0,065 & $-0,731$ & 0,398 & $-7,339^{*}$ & 0 & 3 \\
Corn & $-3,065$ & 0,119 & $-3,112$ & $0,028^{* *}$ & 0,022 & 0,688 & $-8,852^{*}$ & 0 & 1 \\
Cattle & $-2,789$ & 0,204 & $-1,300$ & 0,629 & 0,560 & 0,836 & $-9,642^{*}$ & 0 & 1 \\
Hydrous Ethanol & $-2,882$ & 0,172 & $-2,769$ & 0,065 & 0,537 & 0,831 & $-6,057^{*}$ & 0 & 7 \\
Rice & $-3,287$ & 0,073 & $-3,425$ & $0,018^{* *}$ & $-0,773$ & 0,380 & $-9,794^{*}$ & 0 & 3 \\
Soybean & $-3,092$ & 0,112 & $-2,657$ & 0,084 & $-0,533$ & 0,484 & $-8,784^{*}$ & 0 & 1 \\
Sugar & $-2,463$ & 0,346 & $-2,429$ & 0,136 & 0,217 & 0,748 & $-8,460^{*}$ & 0 & 2 \\
Wheat & $-3,093$ & 0,112 & $-2,345$ & 0,159 & $-0,511$ & 0,494 & $-6,232^{*}$ & 0 & 3 \\
Oil & $-1,448$ & 0,843 & $-1,933$ & 0,316 & $-0,227$ & 0,603 & $-8,884^{*}$ & 0 & 1 \\
Exchange Rate $-0,802$ & 0,962 & $-0,687$ & 0,846 & 0,246 & 0,756 & $-7,722^{*}$ & 0 & 1 & \\
\hline
\end{tabular}

Source: Research data.

* Significant at 1\% level; ** Significant at 5\% level. 


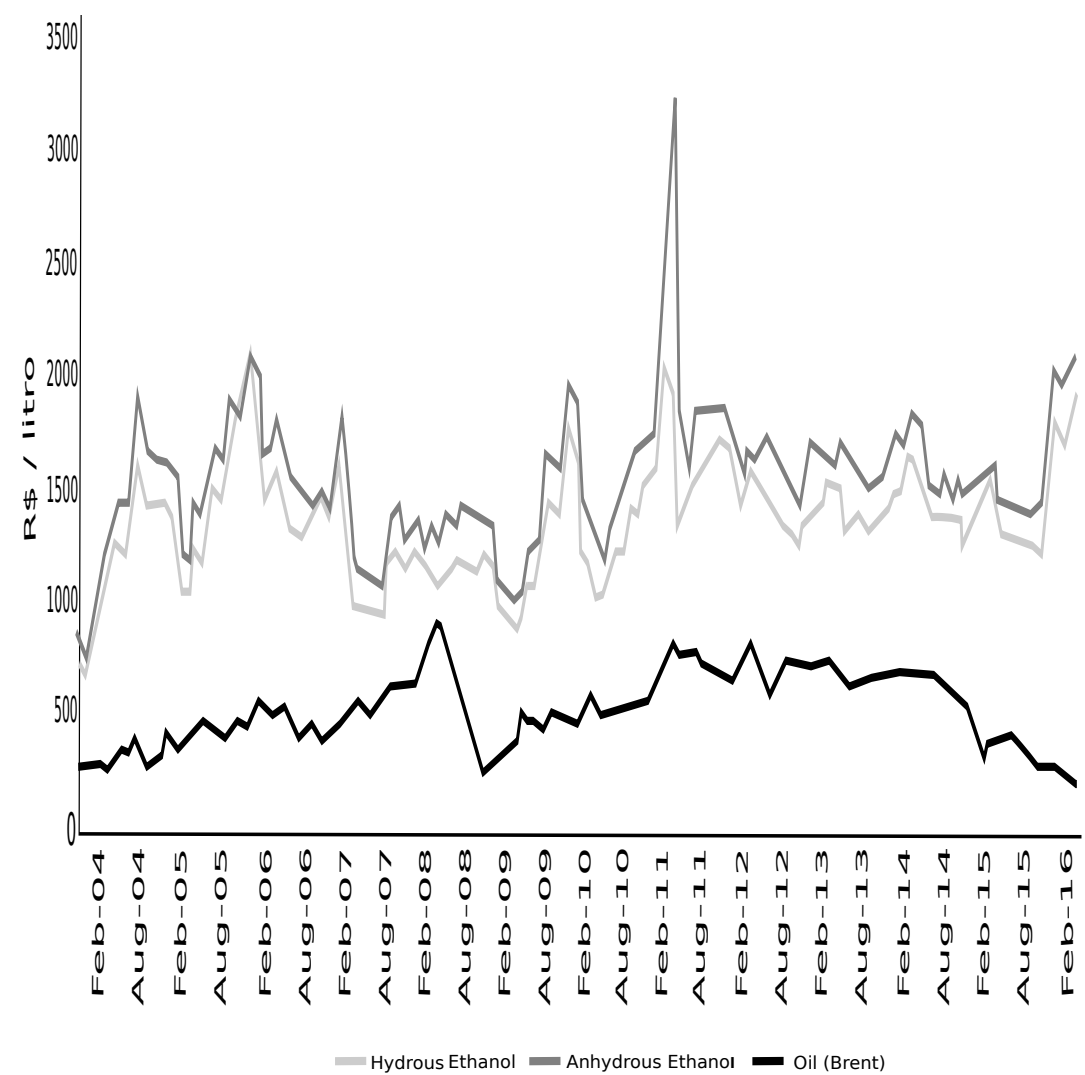

Source: CEPEA (2016), ANP (2016)

Figure 2: Monthly cash prices of fuels in the Brazilian market, 2004-2016

Table 2: Results from DF-GLS unit root test for each variable

\begin{tabular}{lccccc}
\hline & $\tau_{\tau}^{a}$ & \multicolumn{1}{c}{$\tau_{\mu}^{b}$} & $\Delta \tau_{\tau}^{a}$ & $\Delta \tau_{\mu}^{b}$ & Lags \\
\hline Cassava & $-1,868$ & $-1,047$ & $-7,215^{*}$ & $-5,038^{*}$ & 3 \\
Corn & $-2,474$ & $-2,404^{* *}$ & $-8,767^{*}$ & $-8,513^{*}$ & 1 \\
Cattle & $-2,162$ & $-1,205$ & $-9,527^{*}$ & $-9,012^{*}$ & 1 \\
Hydrous Ethanol & $-2,904$ & $-1,177$ & $-4,437^{*}$ & $-2,836^{*}$ & 1 \\
Rice & $-1,171$ & $-0,500$ & $-3,577^{*}$ & $-3,604^{*}$ & 2 \\
Soybean & $-2,169$ & $-1,687$ & $-5,931^{*}$ & $-4,033^{*}$ & 1 \\
Sugar & $-2,113$ & $-1,040$ & $-4,580^{*}$ & $-2,735^{*}$ & 2 \\
Wheat & $-2,915$ & $-1,651$ & $-5,462^{*}$ & $-5,580^{*}$ & 2 \\
Oil & $-1,082$ & $-1,078$ & $-8,815^{*}$ & $-6,822^{*}$ & 1 \\
Exchange Rate & $-0,554$ & $-0,787$ & $-8,120^{*}$ & $-7,478^{*}$ & 1 \\
\hline Source: Researc
\end{tabular}

Source: Research data.

a: Critical values at $1 \%$ and $5 \%$ respectively -3.530 and -2.988 .

b: Critical values at $1 \%$ and $5 \%$ respectively -2.581 and -1.943 .

* Significant at $1 \%$ level; ${ }^{* *}$ Significant at $5 \%$ level. 
Table 3: Results from Johansen cointegration test to the general model

\begin{tabular}{cccrrrrr}
\hline $\mathbf{H}_{\mathbf{0}}:(\mathbf{p}-\mathbf{r})$ & $\mathbf{H}_{\mathbf{A}}: \mathbf{r}$ & Eig. Value & \multicolumn{1}{c}{ Trace } & Trace $^{*}$ & Frac95 & P-value & P-value $^{*}$ \\
\hline 10 & 0 & 0,920 & 598,454 & 576,176 & 239,121 & $0,000^{*}$ & $0,000^{*}$ \\
9 & 1 & 0,369 & 234,039 & 226,287 & 197,220 & $0,000^{*}$ & $0,001^{*}$ \\
8 & 2 & 0,307 & 167,709 & 162,835 & 159,319 & $0,015^{* *}$ & $0,031^{* *}$ \\
7 & 3 & 0,281 & 114,926 & 112,047 & 125,417 & 0,186 & 0,249 \\
6 & 4 & 0,175 & 67,422 & 66,000 & 95,514 & 0,801 & 0,839 \\
5 & 5 & 0,111 & 39,652 & 38,971 & 69,611 & 0,949 & 0,958 \\
4 & 6 & 0,070 & 22,676 & 22,374 & 47,707 & 0,962 & 0,966 \\
3 & 7 & 0,046 & 12,281 & 12,164 & 29,804 & 0,918 & 0,922 \\
2 & 8 & 0,022 & 5,469 & 5,438 & 15,408 & 0,758 & 0,761 \\
1 & 9 & 0,015 & 2,237 & 2,232 & 3,841 & 0,135 & 0,135 \\
\hline
\end{tabular}

Source: Research data.

${ }^{*}$ Significant at $1 \%$ level; ${ }^{* *}$ Significant at $5 \%$ level.

A VECM specifies the short-run dynamics of each price series from a framework that is related to a long-run equilibrium relationship. The first results from the estimation of a structural VECM consist of a matrix of contemporaneous relationships that provide the outputs according to the previous coherent economic structure of each variable's relationship inside the VECM.

Basically, the structure of the VECM was based on a simulation of the influence of ethanol and sugar prices on all crop prices. Also, it is assumed that ethanol and sugar prices affect each other. Another assumption is that oil price is an important variable that can affect all agricultural prices once it impacts the cost of agricultural inputs. The exchange rate is an important variable to be tested against some agricultural prices, especially those with a large interaction in Brazilian international trade, such as exported commodities (soybeans, corn and sugar) and imported commodities (wheat). Finally, some specific interactions may be considered, such as the close association between soybean and corn prices. Finally, as previously mentioned, two dummy variables were considered as exogenous variables ${ }^{5}$.

The estimated coefficients of the influence of simulated variables are expressed in the contemporanous relationship matrix (Table 4$)^{6}$. Overall, six out of twenty estimated coefficients are statistically significant. Supposing a shock to ethanol price, only rice is statistically significant, exhibiting a price increase if the ethanol price increases. Three of five simulated shocks to the exchange rate are significant. Sugar, wheat and soybean reacted significantly to shocks to the exchange rate. Simulated shocks to oil prices only appear to be significant in terms of soybean prices. In addition, soybean price shocks were statistically significant in terms of corn prices, as expected. Non-simulated shocks to sugar were significant, suggesting a weak association of this commodity with other food commodity prices.

Despite the small number of statistically significant coefficients, none of the estimated coefficients and their standard deviations exhibited large ampli-

\footnotetext{
${ }^{5}$ The dummies consider the adjustment for high agricultural commodity price increases during 2008-2009 and the government intervention in gasoline prices since 2011.

${ }^{6}$ After Structural VECM estimation, three residue tests were applied. First, the BreuschGodfrey autocorrelation test suggests no serial correlation between residues in the first lag. Second, the joint variables Jarque-Bera normality test shows that residues are normally multivariate. Third, the joint White heteroskedascity test (not including cross terms) indicated the homogeneity of residue variance, i.e. random variables are homocedastic. Results are available on request.
} 
Table 4: Estimated coefficients in the contemporaneous relationship matrix

\begin{tabular}{|c|c|c|c|c|c|}
\hline $\begin{array}{l}\text { Shocks } \\
\text { From }\end{array}$ & On & $\begin{array}{c}\text { Expected } \\
\text { Signal }\end{array}$ & $\begin{array}{c}\text { Estimated } \\
\text { Coefficients }\end{array}$ & $\begin{array}{l}\text { Std. } \\
\text { Error }\end{array}$ & $\begin{array}{l}\text { Signif. } \\
\text { Level }\end{array}$ \\
\hline Sugar & Ethanol & + & $-0,316$ & 0,802 & 0,693 \\
\hline Oil & Ethanol & + & 0,190 & 0,164 & 0,246 \\
\hline Ethanol & Sugar & + & 0,546 & 0,443 & 0,217 \\
\hline Oil & Sugar & + & 0,044 & 0,103 & 0,667 \\
\hline Exchange Rate & Sugar & + or - & $-0,377$ & 0,193 & $0,051^{* * *}$ \\
\hline Ethanol & Rice & + & 0,107 & 0,057 & $0,058^{* * *}$ \\
\hline Ethanol & Cattle & + & 0,059 & 0,036 & 0,106 \\
\hline Exchange Rate & Cattle & + or - & $-0,078$ & 0,090 & 0,391 \\
\hline Ethanol & Corn & + & 0,087 & 0,056 & 0,117 \\
\hline Soybean & Corn & + & 0,714 & 0,101 & $0,000^{*}$ \\
\hline Oil & Corn & + & 0,029 & 0,066 & 0,662 \\
\hline Exchange Rate & Corn & + or - & 0,013 & 0,156 & 0,936 \\
\hline Ethanol & Soybean & + & $-0,061$ & 0,046 & 0,190 \\
\hline Oil & Soybean & + & 0,165 & 0,053 & $0,002^{*}$ \\
\hline Exchange Rate & Soybean & + or - & 0,403 & 0,126 & $0,001^{*}$ \\
\hline Ethanol & Wheat & + & 0,007 & 0,047 & 0,882 \\
\hline Oil & Wheat & + & 0,082 & 0,053 & 0,125 \\
\hline Exchange Rate & Wheat & + & 0,255 & 0,126 & $0,044^{* *}$ \\
\hline Ethanol & Cassava & + & 0,026 & 0,065 & 0,686 \\
\hline Oil & Cassava & + & $-0,011$ & 0,071 & 0,874 \\
\hline
\end{tabular}

Source: Research data.

* Significant at 1\% level; ** Significant at 5\% level.

tudes, which indicates a reasonable adjustment in the model. The coefficient signs were mostly satisfactory, as expected. The exceptions were the negative value for the impact of ethanol on soybean prices, for sugar on ethanol and the impact of oil price on cassava. All the described exceptions exhibited negative values. In addition, the shocks of exchange rate exhibited different values with different commodities, since some of them are largely exported (sugar, soybean, cattle, corn) or imported (wheat).

In addition to the VECM estimation analysis, the assessment of the variance decomposition of forecast errors for evaluated variables produced some interesting results. Overall, variance decomposition results for crop prices exhibited similar degrees of influence of ethanol prices, oil prices and exchange rate (Figure 3). The participation of these variables in explaining crop prices was generally minor and does not seem to be largely significant. Oil prices and exchange rate had shown slight relevance to most agricultural markets. Only two commodities had more than $5 \%$ of their variance explained by exchange rate, wheat $(8.2 \%)$ and soybean $(6 \%)$, imported and exported in large quantities by Brazil, respectively. Oil prices explained over $5 \%$ of soybean prices (about 6.6\%) only, which is the largest cropped agricultural commodity in Brazil and may be strongly affected by international oil price dynamics. Ethanol had exhibited a large association only with sugar, accounting for $35.1 \%$ of sugar variance. The other crops were explained by $5.5 \%$ (soybean) or less, also suggesting a small influence of ethanol over the explanatory variables.

From the inferences found with other commodities, sugar had little significant influence on other prices. However, soybeans prices had shown a relative importance in explaining corn prices $(24.6 \%)$, and small influence over other markets, highlighting ethanol and sugar prices. Another interesting finding 


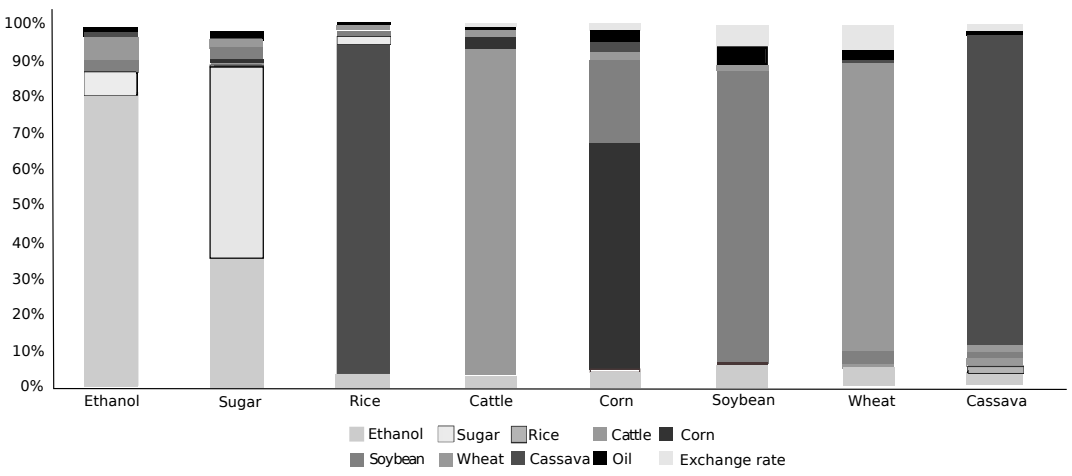

Source: Research data.

Figure 3: Commodity price average variance decomposition of forecast error

is the (small) influence of rice prices on cassava prices; corn prices on cattle prices; and cassava prices on corn prices. These isolated cases suggest that some particular agricultural markets may also be as relevant to explaining crop prices in a similar level as biofuels and oil prices, or some macroeconomic variables, such as the exchange rate. From the estimated results, it is evident that neither ethanol, oil, nor exchange rate had a strong influence over food commodity prices. In comparison to other substitute goods in some markets (e.g. ethanol and sugar; corn and soybean), these variables had weak influence over food price dynamics in Brazil.

The estimation of impulse-response functions supports most of the previous findings. Overall, there is no significant evidence of large increases in prices of commodities after positive shocks in the explanatory variables (ethanol, sugar, oil, and exchange rate). The main results are expressed in Figures 2-6, and represent the cumulative shocks from increases of ethanol, sugar, oil and soybean prices as on the exchange rate.

An ethanol price shock exhibited a significant impact on sugar price (Figure 4). A positive shock to ethanol price (100\%) exhibited significant influence only for sugar prices $(80 \%)$, besides the ethanol price itself $(140 \%)$. Thus, a shock to ethanol price does not seemss to affect prices of food commodities, producing small (rice, cattle and cassava), null (corn and wheat), or slighty negative cumulative impacts (soybean). Similar effects were observed from a sugar price shock on other commodities (Figure 5). Sugar price itself increased about $150 \%$. Unexpectedly, it suggested a negative effect on ethanol price $(-30 \%)$ and no increase in food commodity prices. These findings may suggest that, irrespective of the reason for the fast increase in Brazilian sugarcane production (i.e. the harvest destination for sugar or ethanol production), it seems that positive shocks for both commodity prices may not have dramatic effects on the boundary agricultural markets (prices).

Following the process of shock simulation on explanatory variables, a positive shock in oil prices also showed weak effects on prices of agricultural commodities, as observed previously from the effect of shocks on ethanol and sugar prices. However, it seems to be higher than those simulated price shocks to ethanol or sugar prices. For example, wheat, soybean, corn, sugar, and ethanol exhibited a small increase, from $10 \%$ to $20 \%$ (Figure 6), especially in the first and second period after the oil shock, indicating that some agricul- 


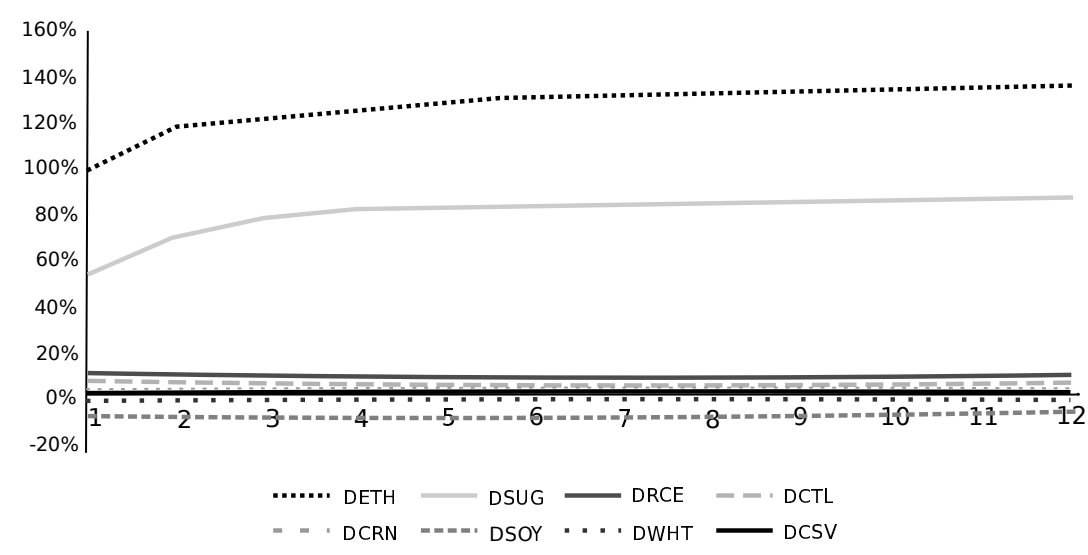

Source: Research data.

Figure 4: Impulse-response function from a given ethanol price shock

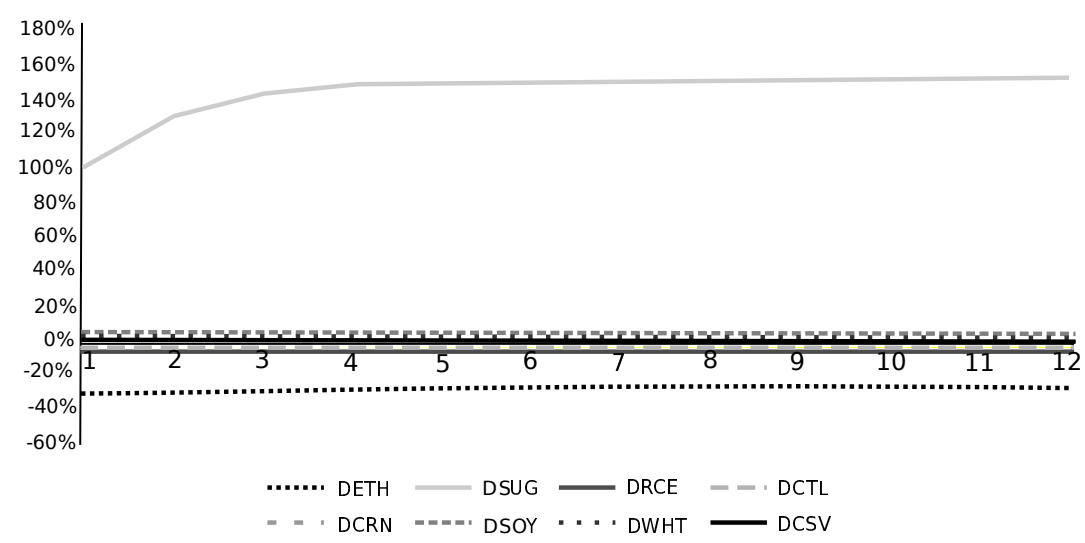

Source: Research data.

Figure 5: Impulse-response function from a given sugar price shock

tural markets tend to react quickly (but not expressively) to oil shock, by cost increases, being able to recover their market equilibrium in the short-run. In addition, there was no impact of oil prices on cattle, cassava and rice prices.

The simulated exchange rate shock caused increases in some agricultural commodity prices (as well as price volatility). Overall, a positive shock (100\%) in this variable resulted in moderate price increases for soybean $(40 \%)$, wheat and corn $(32 \%)$, cassava $(20 \%)$, and ethanol $(8 \%)$, which are mostly Brazilian agricultural markets largely associated with international trade (Figure 7). In the short-run, some impacts may be greater, as observed in the simulated oil price shocks, possibly by the increasing (decreasing) the cost of production (margins). It is important to highlight an important issue concerning the Brazilian exchange rate during the period of the study. From 2004 to 2013, the exchange rate was relatively stable, exhibiting no large deviations as in earlier periods. After 2014, a significant currency devaluation affected the Brazilian exchange rate. So, the impulse-response findings suggest that moderate variations in the exchange rate may incur similar or larger impacts on Brazilian agricultural prices than fuel prices.

In addition to the most relevant variables considered to have more in- 


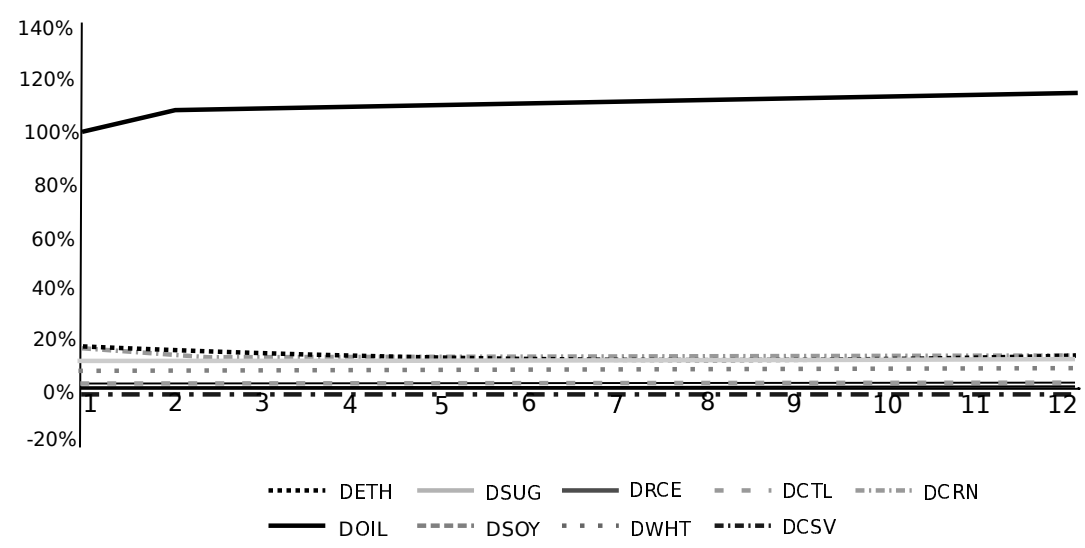

Source: Research data.

Figure 6: Impulse-response function from an oil price shock

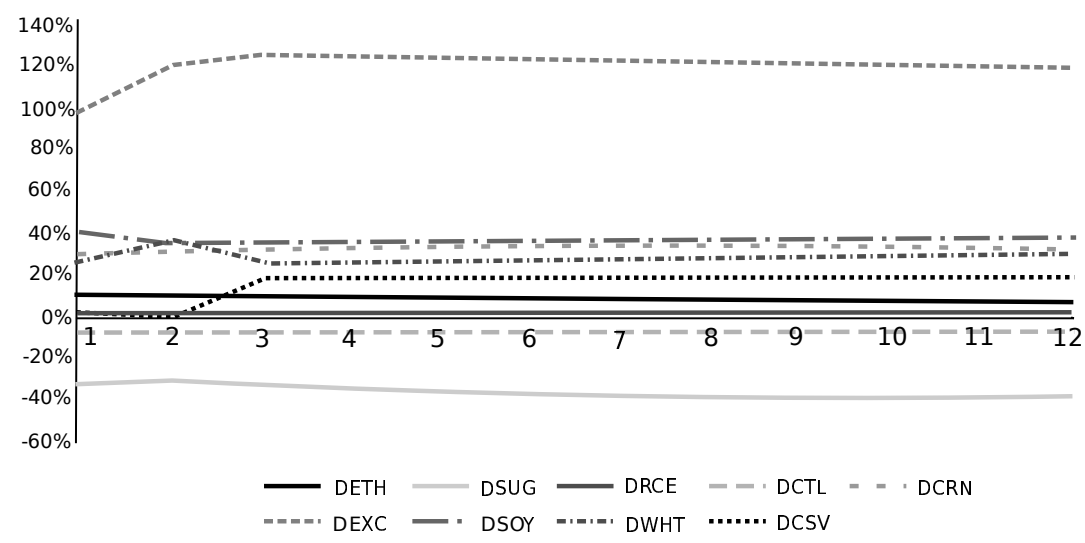

Source: Research data.

Figure 7: Impulse-response function from a given exchange rate shock

fluence over other food commodity prices, a simulated soybean price shock showed an interesting result (Figure 8). This commodity is much more relevant to explaining the increase in other prices than exchange rate, ethanol, sugar, or oil prices. A shock in soybean prices (100\%) may sustain significant increases in corn prices (above 100\%), as well as in domestic soybean prices themselves (135\%). In addition, this shock may increase ethanol and sugar prices by $40 \%$ (the opposite was not observed, as indicated in Figure 3 and $4)$. The only commodity price not affected by soybean was cattle. These findings suggest that soybean, the largest volume crop harvested in Brazil ${ }^{7}$, may strongly influence other agricultural markets, even more significantly than other variables such as sugar, ethanol, oil, or exchange rates.

Summarizing the results presented in Figures $3-8$, it is possible to note that Brazilian ethanol cannot be associated with positive price influences in regional food markets. This biofuel had even less impact on the dynamics of food prices than other commodities, such as soybean and oil, or macroeco-

\footnotetext{
${ }^{7}$ Brazil is the largest soybean exporter and the second largest producer. Soybean harvested area in Brazil was close to 32 million hectares in 2015, and corn and sugarcane harvested areas close to 22 million and 9 million hectares, respectively (CONAB 2016).
} 


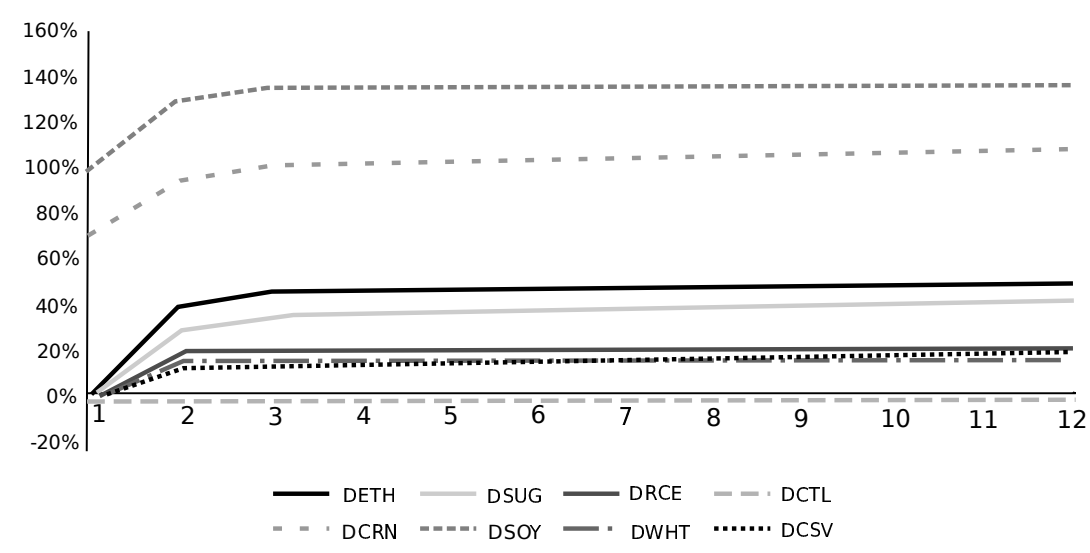

Source: Research data.

Figure 8: Impulse-response function from a given soybean price shock

nomic indicators, such as exchange rate. Further, results presented in Figure 3 suggest that ethanol is closely associated with sugar prices, indicating that its price is much more associated with some particular economic and technical issues inside the domestic sugarcane production chain.

\section{Conclusions}

The purpose of this study was to investigate the impact of the expansion of sugarcane ethanol production in Brazil on domestic agricultural/food commodity markets. In particular, this research focused on price analysis and the long- run relationships of fuels and agricultural prices. The study proposed the use of cointegration analysis, as well as the estimation of an autoregressive vector model with errors correction (VECM). The structural VECM applied for the most reasonable associations between the considered variables proposed the identification of the main causality effects from positive shocks in key independent variables, such as ethanol, sugar and oil prices, and exchange rate.

General results showed that, regarding the expansion of sugarcane and ethanol production in Brazil over the past years, the prices of agricultural commodities do not seem to be affected by biofuel production at the domestic level. The model outputs suggested that there are no significant effects of ethanol (or sugar) prices on the price of major consumed crops. These findings emphasize one related issue discussed in the price analysis literature regarding the previous research topics. The paper conclusion is connected to other recent studies that used time series models to capture prices, long-run relationship and causality to assess the impact of biofuel production on food prices. In the Brazilian context, the general results connected to the main findings described by Balcombe \& Rapsomanikis (2008) and Kristoufek et al. (2015) in two studies focused on fuel and food interactions considering the Brazilian market. However, as pointed out, these studies concentrated their analysis on the interactions between ethanol, oil, gasoline, and sugar prices, ignoring food commodities that could highlight the problem of food security, or macroeconomic variables that usually affect the behavior of prices at the domestic level.

Although the long-run relationship of the variables is considered in the 
model, it is not possible to affirm that ethanol is the most important variable for explaining commodity prices. According to the results of VECM estimation, it is possible to observe that oil prices and exchange rate had a similar (or larger) impact on agricultural prices than ethanol prices, which in turn can also explain the three cointegration vectors found using the Johansen test estimation.

The VECM results showed similar effects of ethanol, sugar, oil, and exchange rate on agricultural prices. These effects are mostly of low significance to explain commodity price discovery. Consequently, the importance of Brazilian biofuels as an explanation for agricultural prices is equivalent to (or less than) the effects resulting from shocks on oil prices or exchange rate. It is important to note that soybean had a significant impact on other agricultural food commodities, especially corn, highlighting that the largest grain harvest in the country must have much more influence on general food markets than sugarcane outputs, such as ethanol and sugar.

Therefore, the inclusion of one relevant macroeconomic variable, such as exchange rate, contributed to calibration of the biofuel and fuel model and to an understanding that some particular variables can give a better adjustment to the model. Taking this into consideration, an interesting question would be to explore the influence of local macroeconomic and microeconomic conjunctures in the analysis of food prices. For example, developing countries tend to exhibit much greater volatility in their exchange rate than developed countries. If their agricultural commodities are exported (imported), as in Brazil, it would be desirable to consider this variable in a model. Similar assumption is associated to the impact of soybean over corn prices, which reflect a strong relationship between the two largest crops in this country. This shows that these commodities, which also affect protein prices, such as cattle, dairy, poultry and pork, might have a large influence on each other and not necessarily have any connection with the recent sugarcane expansion in Brazil.

It is important to note that the research results should be understood with caution and interpolated with other study results that applied different economic models as, for example, the general or partial equilibrium models considering land use issues. Still, one reason that could explain this null influence of ethanol prices is the government intervention in the gasoline production, prices and distribution in the Brazilian market, especially during the period of 2008-2015. The Brazilian federal government has adopted a policy to control gasoline prices in order to maintain the economic policy goals regarding desirable inflation targets. Gasoline prices have been stabilized, discouraging higher increases in ethanol (biofuel) prices. Thus, ethanol prices are not flowing as in a free trade market (also corroborated by the low international trade and the absence of a referenced price discovery market). Considering this issue, new modeling adjustments are desirable in futures studies. One alternative approach is expanding data periodicity or including additional analysis to understand the long-run relationship between gasoline, biofuels and crop prices.

Overall, the findings of this study can offer new insights on the foodbiofuel debate in a developing economy. In addition, this study might provide new perceptions, once it assesses a market where sugarcane ethanol is important and does not promote direct competition with feed production, such as corn ethanol. The adoption of time series models can provide an alternative methodological approach to the previous research investigations, with a com- 
prehensive study which includes several commodities important for domestic food security. In particular, results can shed light on the discussion of social and economic sustainability of biofuels and on future policies regarding biofuel production incentives.

\section{Bibliography}

ABIOVE (2016), 'Biodiesel: production and delivery'. Brazilian Association of Vegetable Oil Industries.

URL: $h t t p: / / w w w . a b i o v e . o r g . b r$

Ajanovic, A. (2011), 'Biofuels versus food production: does biofuels production increase food prices?', Energy 36(4), 2070-2076.

ANP (2016), 'Statistical data: fuel'. National Agency of Petroleum, Natural Gas and Biofuels.

URL: $h t t p: / / w w w . a n p . g o v . b r$

Balcombe, K. \& Rapsomanikis, G. (2008), 'Bayesian estimation and selection of nonlinear vector error correction models: the case of the sugar-ethanol-oil nexus in Brazil', American Journal of Agricultural Economics 90(3), 658-668.

Bernanke, B. S. (1986), Alternative explanations of the money-income correlation, in 'Carnegie-Rochester Conference Series on Public Policy,', Vol. 25, pp. 44-100.

CEPEA (2016), 'Prices indexes'. Center for Advanced Studies On Applied Economics.

URL: $h t t p: / / w w w . c e p e a . e s a l q . u s p . b r$

Chen, S. T., Kuo, H. J. \& Chen, C. C. (2010), 'Modeling the relationship between the oil price and global food prices', Applied Energy 87(1), 2517-2525.

Chen, X. \& Khanna, M. (2013), 'Food vs. fuel: the effect of biofuel policies', American Journal of Agricultural Economics 95(2), 289-295.

CONAB (2016), 'Harvest and production data'. National Food Supply Agency.

URL: http://www.conab.gov.br

Drabik, D., Gorter, H., Jus, D. R. \& Tilmisina, G. R. (2015), 'The economics of Brazils ethanol-sugar markets, mandates, and tax exemptions', American Journal of Agricultural Economics 97(5), 1433-1450.

Elbehri, A., Segerstedt, A. \& Liu, P. (2013), Biofuels and sustainability challenge: a global assessment of sustainability issues, trends and policies for biofuels and related feedstocks, FAO, Rome, p. 188.

Enders, W. (2004), Applied econometrics time series, John Wiley \& Sons.

Hamilton, J. D. (1944), Time series analysis, Princeton University Press.

Hochman, G. Kaplan, S., Rajagopal, D. \& Zilberman, D. (2012), 'Biofuels and food-commodity prices', Agriculture 2(3), 275-281. 
Hochman, G., Rajagopal, D., Timilsina, G. \& Zilberman, D. (2011), The role of inventory adjustments in quantifying factors causing food price inflation. Working Paper 5744, World Bank.

Johansen, S. (1988), 'Statistical analysis of cointegration vectors', Journal of Economics Dynamics and Control 12(1), 231-254.

Kristoufek, L., Janda, K. \& Zilberman, D. (2014), 'Price transmission between biofuels, fuels, and food commodities', Biofuels, Bioproducts $\mathcal{E}$ Biorefining 8(1), 362-373.

Kristoufek, L., Janda, K. \& Zilberman, D. (2015), 'Co-movements of ethanol related prices: evidence from Brazil and the USA', GCB Bioenergy 8(2), 346356.

Martinez, S. H., Eijck, J. V., Cunha, M. P., Guilhoto, J. M., Walter, A. \& Faaij, A. (2013), 'Analysis of socio-economic impacts of sustainable sugarcane-ethanol production by means of inter-regional input-output analysis: demonstrated for northeast brazil', Renewable \& Sustainable Energy Reviews 28(1), 290-316.

Nassar, A. M., Harfuch, L., Bachion, L. C. \& Moreira, M. R. (2011), 'Biofuels and land-use changes: searching for the top model', Interface Focus 1(1), 224 232.

Ng, S. \& Perron, P. (2001), 'Lag length selection and the construction of unit root tests with good size and power', Econometrica 69(6), 1519-1554.

Nuñez, H. M., Önal, H. \& Khanna, M. (2013), 'Land use and economic effects of alternative biofuel policies in Brazil and United States', Agricultural Economics 44(1), 487-499.

Rajagopal, D., Sexton, S. E., Roland-Holst, D. \& Zilberman, D. (2007), 'Challenge of biofuel: filling the tank without emptying the stomach?', Environmental Research Letter 2(1), 1-9.

Rapsomanikis, G. \& Hallam, D. (2006), Threshold cointegration in the sugarethanol-oil price system in Brazil: evidence from nonlinear vector error correction models, in 'Commodity and Trade Policy Research Working Paper', number 22, Rome: FAO.

Serra, T. (2011), 'Volatility spillover between food and energy market: a semiparametric approach', Energy Economics 33(1), 1155-1164.

Serra, T. \& Zilberman, D. (2013), 'Biofuel-related price transmission literature: a review', Energy Economics 37(1), 141-151.

Serra, T., Zilberman, D., Gil, J. M. \& Goodwin, B. K. (2011a), 'Price volatility in ethanol markets', European Review of Agricultural Economics 38(1), 259280.

Serra, T., Zilberman, D., Gil, J. M. \& Goodwin, B. K. (2011b), 'Nonlinearities in the US corn-ethanol-oil prices system', Agricultural Economics 42(1), 3545 . 
Sexton, S., Rajagopal, D., Zilberman, D. \& Hochman, G. (2008), 'Food versus fuel: how biofuels make food more costly and gasoline cheaper?', Agricultural and Economic Resource 12(1), 1-6.

Sims, C. A. (1986), 'Are forecasting models usable for policy analysis?', Federal Reserve Bank of Minneapolis Quarterly Review 10(1), 2-16.

Timilsina, G., Mevel, S. \& Shrestha, A. (2011), 'Oil price, biofuels and food supply', Energy Policy 39(1), 8098-8105.

Vacha, L., Karrel, J., Kristoufek, L. \& Zilberman, D. (2013), 'Time-frequency dynamics of biofuel-fuel-food system', Energy Economics 233-241(40), 1.

Zhang, Z., Lohr, L., Escalante, C. \& Wetzstein, M. (2009), 'Ethanol, corn and soybean price relations in a volatile-vehicle fuels market', Energies 2(1), 230 239.

Zhang, Z., Lohr, L., Escalante, C. \& Wetzstein, M. (2010), 'Food versus fuel: what do prices tell us?', Energy Policy 38(1), 445-451.

Zilberman, D., Hochman, G., Rajagopal, D., Sexton, S. \& Timilsina, G. (2012), 'The impact of biofuels on commodity food prices: assessment of findings', American Journal of Agricultural Economics 95(2), 275-281. 
